\title{
BNYVV-derived dsRNA confers resistance to rhizomania disease of sugar beet as evidenced by a novel transgenic hairy root approach
}

\author{
Ourania I. Pavli • Nicholas J. Panopoulos • \\ Rob Goldbach · George N. Skaracis
}

Received: 12 May 2009/Accepted: 5 January 2010/Published online: 3 February 2010

(C) The Author(s) 2010. This article is published with open access at Springerlink.com

\begin{abstract}
Agrobacterium rhizogenes-transformed sugar beet hairy roots, expressing dsRNA from the Beet necrotic yellow vein virus replicase gene, were used as a novel approach to assess the efficacy of three intron-hairpin constructs at conferring resistance to rhizomania disease. Genetically engineered roots were similar in morphology to wild type roots but were characterized by a profound abundancy, rapid growth rate and, in some cases, plagiotropic development. Upon challenge inoculation, seedlings showed a considerable delay in symptom development compared to untransformed or vector-transformed seedlings, expressing dsRNA from an unrelated source. The transgenic root system of almost all seedlings contained no or very low virus titer while the nontransformed aerial parts of the same plants were found infected, leading to the conclusion that the hairy roots
\end{abstract}

O. I. Pavli ( $\square) \cdot$ R. Goldbach

Department of Plant Sciences, Laboratory of Virology, Wageningen University, Droevendaalsesteeg 1,

6708 PB Wageningen, The Netherlands

e-mail: ourania.pavli@wur.nl; raniapavli@yahoo.com

O. I. Pavli · G. N. Skaracis

Department of Crop Sciences, Laboratory of Plant Breeding and Biometry, Agricultural University of Athens, Iera Odos 75, 11855 Athens, Greece

\section{N. J. Panopoulos}

Department of Biology, Section of Biotechnology and Applied Biometry, University of Crete, Vasilika Vouton, 71409 Heraklio, Crete, Greece studied were effectively protected against the virus. This readily applicable novel method forms a plausible approach to preliminarily evaluate transgenic rhizomania resistance before proceeding in transformation and whole plant regeneration of sugar beet, a tedious and time consuming process for such a recalcitrant crop species.

Keywords Beta vulgaris . Beet necrotic yellow vein virus - Agrobacterium rhizogenes . Transformation $\cdot$ Sugar beet $\cdot$ Rhizomania

\section{Introduction}

Rhizomania disease is caused by Beet necrotic yellow vein virus (BNYVV) (Tamada and Baba 1973), which is vectored and transferred to sugar beet healthy roots by the widespread soilborne plasmodiophorid fungus Polymyxa betae Keskin. Due to a dramatic reduction in root yield, sugar content and purity when susceptible cultivars are grown, the potential sugar yield losses may reach up to $90 \%$ (Johansson 1985). Consequently, the economic viability of the crop is largely dependent on the successful protection against rhizomania. The only practical means of combating this most devastating disease is the use of genetically resistant varieties and therefore, all relevant breeding activities become of paramount importance. All cultivars in commercial use have been developed through 
conventional breeding methods, including markerassisted backcross breeding approaches (for a review, see De Biaggi 2005). Despite breeding progress, a better yield is needed under disease conditions and, various genetic engineering approaches are also being employed to further improve disease resistance (for a review, see Skaracis 2005). Among these, RNA silencing-mediated resistance has recently attracted special interest (Andika et al. 2005; Lennefors et al. 2006).

RNA silencing is a highly conserved mechanism that occurs in a wide range of eukaryotic organisms, including animals (RNA interference, RNAi), plants (post-transcriptional gene silencing, PTGS) and fungi (quelling), and functions as an innate defense system against alien nucleic acid molecules (Voinnet 2001; Tijsterman et al. 2002). The mechanism is a RNAbased process acting in a sequence-specific manner to control gene expression either at a transcriptional or post-transcriptional level (Baulcombe 1999; Brodersen and Voinnet 2006). A key feature of RNA silencing refers to its role as an active defense system against viral invaders in plants and invertebrates (Ding and Voinnet 2007) and against transposable elements in mammals (Tabara et al. 1999; Kalmykova et al. 2005; Vagin et al. 2006). The triggering element of all existing RNA silencing pathways is a dsRNA molecule, capable of recruiting necessary components to carry out sequential phases of sequence-specific degradation (Fire et al. 1998; Hammond et al. 2001). Following recognition, dsRNA is cleaved by the nuclease DICER, a member of an RNase III-like enzyme family, and processed into short, 21-23 nucleotides in length, interfering RNAs with 2ntoverhangs at the 3' ends (siRNAs) (Hamilton and Baulcombe 1999; Bernstein et al. 2001). After strand separation, unwound ssRNAs are incorporated into the RNA-induced silencing complex (RISC) and serve as guides for recognition of homologous RNAs in the cytoplasm, leading to inhibition of transcript stability or translation (Hammond et al. 2000; Song et al. 2004; Hammond 2005).

Since its discovery, RNA silencing (Napoli et al. 1990; van der Krol et al. 1990) has been used in gene knock down studies in a variety of eukaryotic organisms (Fire et al. 1998; Ngo et al. 1998; Lohmann et al. 1999; Smith et al. 2000). In plants, RNA silencing primarily aims at the development of antiviral activity (Voinnet 2001, 2008; Waterhouse et al. 2001; Vazquez et al. 2002; Goldbach et al. 2003; Tenllado et al. 2004), but is also employed in transposon silencing, transcriptional gene silencing due to DNA methylation, chromatin condensation and as a tool for gene regulation studies (Stam et al. 1997; Hamilton et al. 2002; Brodersen and Voinnet 2006). The mechanism is usually triggered by the introgression of transgene constructs, arranged as inverted repeats ("hairpin" molecules), capable of duplex RNA formation (Hamilton et al. 1998; Waterhouse et al. 1998; Chuang and Meyerowitz 2000; Johansen and Carrington 2001).

The aim of this work was to study three different hairpin constructs, carrying parts of a highly conserved region from the replicase gene of BNYVV, in conferring transgenic resistance to the rhizomania disease. As is well known, sugar beet is particularly recalcitrant to transformation species requiring a tedious, time consuming and costly procedure to obtain a satisfactory number of successfully transformed and regenerated plants (D' Halluin et al. 1992; Krens et al. 1996; Wozniak 1999). In the light of such difficulties, we have developed a novel method for A. rhizogenesmediated production of plants with a transgenic hairy root system and non-transformed shoots and leaves to allow for the evaluation of transgene effect on virus accumulation. Such a shortcut approach can be easily employed and would be of significant value in providing relevant information prior to effecting the laborious and problematic transformation and whole plant regeneration.

\section{Materials and methods}

Construction of plant expression vectors

Three intron-hairpin constructs from the BNYVV replicase gene, encoded by RNA1, were assembled and used for A. rhizogenes-mediated transformation. Total RNA extracted from BNYVV-infected sugar beet roots was reversed transcribed using genespecific primers and the Im-Prom II Reverse Transcriptase System (Promega) and used as template for PCR to obtain 459,589 and 824 bp fragments with primer pairs GWAttb 1 F-GWAttb $21 R$, GWAttb 2 FGWAttb $_{2} 1 R$ and GWAttb 2 F-GWAttb 2 , respectively (Table 1 ). PCR reaction mixture contained $2.5 \mu \mathrm{l}$ cDNA, $0.5 \mu \mathrm{M}$ of each primer, $200 \mu \mathrm{M}$ dNTPs, $1 \times$ HF buffer and $1 \mathrm{u}$ of high fidelity DNA 
Table 1 Primers used to obtain the BNYVV replicase-derived transgene sequences

\begin{tabular}{|c|c|c|c|}
\hline Primer & Sequence $\left(5^{\prime} \rightarrow\right.$ 3') & nt position & Product size (bp) \\
\hline GWAttb $_{1} 1 \mathrm{~F}$ & $\begin{array}{l}\text { GGGGACAAGTTTGTACAAAAAAGCAGGCT } \\
\text { TTTCTGACTTCTTTTTGGATTG }\end{array}$ & RNA 1: 5750 & \\
\hline GWAttb $_{2} 1 \mathrm{R}$ & $\begin{array}{l}\text { GGGGACCACTTTGTACAAGAAAGCTGGGT } \\
\text { TCAAGATAGGAGGCCTGTGGCAT }\end{array}$ & RNA 1: 6574 & 824 (GW-IR2) \\
\hline GWAttb $_{1} 2 \mathrm{~F}$ & $\begin{array}{l}\text { GGGGACAAGTTTGTACAAAAAAGCAGGCT } \\
\text { CGAAGATAGCAGCACACAGGTTC }\end{array}$ & RNA 1: 6116 & \\
\hline GWAttb $_{2} 2 \mathrm{R}$ & $\begin{array}{l}\text { GGGGACCACTTTGTACAAGAAAGCTGGGT } \\
\text { TTCACACCCAGTCAGTACA }\end{array}$ & RNA 1: 6704 & $589(\mathrm{GW}-\mathrm{IR} 1)$ \\
\hline
\end{tabular}

polymerase (Phusion High Fidelity DNA polymerase, Finnzymes) in a volume of $50 \mu \mathrm{l}$. Amplification cycles included a first denaturation cycle of $30 \mathrm{~s}$ at $98^{\circ} \mathrm{C}$, then 35 cycles composed of $10 \mathrm{~s}$ at $98^{\circ} \mathrm{C}, 30 \mathrm{~s}$ at $60^{\circ} \mathrm{C}, 45 \mathrm{~s}$ at $72^{\circ} \mathrm{C}$ with a final elongation cycle of $10 \mathrm{~min}$ at $72^{\circ} \mathrm{C}$. PCR-amplified products were subsequently eluted from agarose gels and used for the development of recombinant plasmids using the Gateway Cloning Technology (Invitrogen), according to the instruction manual. Amplicons corresponding to BNYVV replicase gene were initially introduced by a recombination reaction using Gateway BP clonase enzyme mix to pDONR 221, leading to the creation of entry clones. Transgenes were subsequently recombined with the destination vector pK7WIWG2 (II) (Karimi et al. 2002) carrying neomycin phosphotransferase II (nptII) as a selectable marker gene, using Gateway LR clonase enzyme mix, to generate the binary plant expression vectors GW-IR1, GW-IR2 and GW-IR3. Following restriction digestion, for the confirmation of integrity and orientation of the hairpin structure, plasmid DNA was rescued from transformed $E$. coli cells and sequenced using M13 forward and reverse primers.

\section{Bacterial strains}

The A. rhizogenes strain R1000 harbouring the plasmid pRiA4 was used to transform sugar beet seedlings. The binary plant expression vectors GW-IR1, GW-IR2, GW-IR3 and the destination vector pK7WIWG2 (II), carrying the $c c d B$ gene, were introduced to A. rhizogenes cells by electroporation and grown at $28^{\circ} \mathrm{C}$ under spectinomycin $\left(50 \mu \mathrm{g} \mathrm{ml}^{-1}\right)$ and nalidixic acid $\left(25 \mu \mathrm{g} \mathrm{ml}^{-1}\right)$ selection for 2 days or until $\mathrm{OD}_{600}=0.6-1.0$ was reached. Bacterial cells were collected by centrifugation for $10 \mathrm{~min}$ at $1,500 \mathrm{rpm}$ and the pellet was used as inoculum for plant transformation.

Plant material

Transformation experiments were carried out using the commercial sugar beet variety Alexandra, which is a diploid, monogerm, three-way top cross hybrid (EU Common Variety Catalogue, ed. 27, E297A/2011-2008). Alexandra is a standard cercospora leaf spot resistant-rhizomania susceptible variety.

\section{A. rhizogenes-mediated transformation and evaluation of transformed roots}

Transformation was performed on 9 day-old aseptically grown sugar beet seedlings by removing the existing root system and dipping the wounded surface of hypocotyl into the bacterial cells. Inoculated seedlings were co-cultivated for 3 days $\left(23^{\circ} \mathrm{C}, 16 / 8 \mathrm{~h}\right.$ light/ darkness) in square petri dishes containing co-cultivation medium ( $1 / 2 \mathrm{MS}$ basal salts, $1 \%$ sucrose, $0.9 \%$ PhytoAgar), half-covered with filter paper and subsequently transferred to selection medium ( $1 / 2 \mathrm{MS}$ containing 2-MorpholinoEthaneSulfonic acid (MES) and vitamins $\left(1 \mu \mathrm{g} \mathrm{ml}^{-1}\right.$ glycine, $50 \mu \mathrm{g} \mathrm{ml}^{-1}$ myoinositol, $0.25 \mu \mathrm{g} \mathrm{ml}^{-1}$ nicotinic acid, $0.25 \mu \mathrm{g} \mathrm{ml}^{-1}$ pyridoxine $\mathrm{HCl}, 0.05 \mathrm{~g} \mathrm{ml}^{-1}$ thiamine $\left.\mathrm{HCl}\right), 2 \%$ sucrose, $0.9 \%$ PhytoAgar, cefotaxime $\left(250 \mu \mathrm{g} \mathrm{ml}^{-1}\right)$ and kanamycin $\left.\left(150 \mu \mathrm{g} \mathrm{ml}^{-1}\right)\right)$. Petri dishes were partially sealed and placed vertically in a growth 

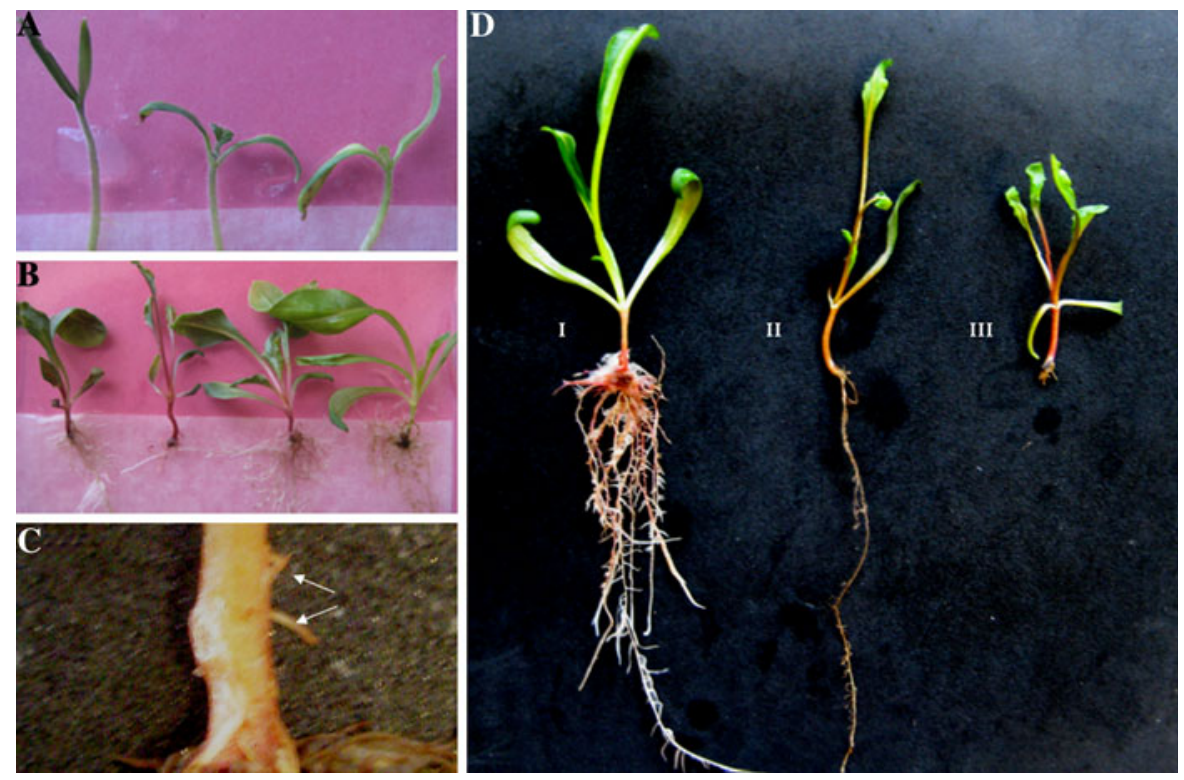

Fig. 1 Production of transgenic sugar beet hairy roots. a A. rhizogenes-inoculated seedlings $(0 \mathrm{dpt})$ grown vertically on square Petri dishes with a filter paper. b Hairy root formation at $10 \mathrm{dpt}$ with A. rhizogenes strain $\mathrm{R} 1000$. c Emergence of adventitious lateral roots as a response to sectioning. $\mathbf{d}$ Use of kanamycin for the selection of transgenic hairy roots on

chamber (Fig. 1a). After growth for 7-10 days, seedlings were regularly monitored for the emergence of new roots and those with well developed hairy roots were transferred and maintained in $1 / 2$ MS basal salt liquid medium under kanamycin selection. Untransformed sugar beet seedlings obtained by cutting at the hypocotyl, removing the existing root system and grown with or without antibiotic selection, were included as experimental controls.

Kanamycin-resistant sugar beet roots were evaluated for the presence and expression of the cassette and for absence of $A$. rhizogenes cells. Transgene presence and absence of A. rhizogenes was examined by a multiplex PCR assay targeting the nucleotide sequences of the BNYVV replicase transgene, the $n p t \mathrm{II}$ gene and virCD of $A$. rhizogenes, using FTA (Whatman)-immobilized nucleic acids as template for amplification. Targeted sequences were amplified using the following primer pairs: GWAttb 1 FGWAttb $_{2} 1 \mathrm{R}$, GWAttb $_{1} 2 \mathrm{~F}-\mathrm{GWAttb}{ }_{2} 1 \mathrm{R}$ and GWAttb 2F-GWAttb 2 2R for transgenes, $n p t I I$ F: AGTGA-CAA CGTCGAGCACAG- $n p t I I$ R: GCGTTCAAAAGTC GCCTAAG for $n p t I I$ and $v i r C D$ F: CTCATCAGG CACGCTTG-virCD R: GCGGATGCTTCAAATGG composite sugar beet seedlings. I Seedling grown on medium containing kanamycin $\left(150 \mu \mathrm{g} \mathrm{ml}^{-1}\right), 10$ days after sectioning and inoculation with $A$. rhizogenes strain $\mathrm{R} 1000$. II Untransformed seedling under no antibiotic selection. III Untransformed seedling grown on kanamycin-containing medium

for $\operatorname{vir} C D$. PCR reaction mixture contained template DNA corresponding to $2 \mathrm{~mm}$ FTA-saturated with root tissue, $0.25 \mu \mathrm{M}$ of each primer, $200 \mu \mathrm{M}$ dNTPs, $1.25 \mathrm{mM} \mathrm{MgCl} 2,1 \times$ Taq buffer and $1.25 \mathrm{u} \mathrm{Taq}$ polymerase (GoTaq Flexi DNA polymerase, Promega) in a final volume of $20 \mu \mathrm{l}$. Amplification cycles included a cycle of $3 \mathrm{~min}$ at $94^{\circ} \mathrm{C}$, then 30 cycles composed of $30 \mathrm{~s}$ at $94^{\circ} \mathrm{C}, 1 \mathrm{~min}$ at $50^{\circ} \mathrm{C}, 1 \mathrm{~min}$ at $72^{\circ} \mathrm{C}$ with a final cycle of $7 \mathrm{~min}$ at $72^{\circ} \mathrm{C}$. Amplification products were visualized in agarose gels stained with ethidium bromide. For the evaluation of transgene expression, total RNA was isolated with the SV Total RNA Isolation Kit (Promega) and used as a template in a two step RT-PCR assay targeting the sequences of the inserted transgenes, using the primer pairs and reaction conditions previously described.

\section{Virus inoculations}

Heavily BNYVV-infected sugar beet plants were used as virus source for the inoculation of transformed roots. Inoculum was prepared by grinding infected sugar beet root tissue $(1: 5 \mathrm{w} / \mathrm{v})$ in $0.05 \mathrm{M}$ phosphate buffer containing $0.01 \% \mathrm{Na}_{2} \mathrm{SO}_{3}, \mathrm{pH}-7.2$. 
Seedlings were mechanically inoculated by a vortex method adapted from Koenig and Stein (1990). Seedlings were individually placed into test tubes and inoculated by pouring the crude extract (1-1.5 ml per tube) and carborundum as a means to artificially create wounds. Following gentle agitation for at least $3 \mathrm{~h}$, seedlings were subsequently maintained in $1 / 2$ MS basal salt liquid medium. Vector-transformed seedlings, carrying the $c c d B$ gene, and untransformed seedlings served as susceptible controls, whereas untransformed seedlings non-challenged by the virus were included as experimental negative controls.

\section{Assessment of virus resistance}

Each seedling was individually analyzed. Seedlings were initially rinsed with tap water to avoid any probable presence of inoculum on the surface of roots and subsequently dried in paper towels. Plant sap from root and leaf tissue was separately extracted in a 1:3 or 1:5 (weight:volume) extraction buffer. Virus titers were measured 14 and 21 days post inoculation (dpi) by DAS-ELISA (Biorad). Each leaf and root sample of the individual seedlings was replicated twice in the plate. Absorbance values at $405 \mathrm{~nm}$ measured at least three times the respective measurement of the negative controls were considered as positive.

Data were analyzed, when appropriate, using the statistical package JMP v.6. The differences among root and leaf ELISA readings were statistically compared by a paired $t$-test, based on the respective readings of each individual seedling. ELISA readings on leaves of the four categories tested (three constructs and control) were analyzed by ANOVA and the means were compared by the F protected LSD.

\section{Results and discussion}

Production and evaluation of Ri T-DNAtransformed sugar beet hairy roots in seedlings

With the purpose of evaluating the potential of RNA silencing to control BNYVV in genetically engineered sugar beet hairy roots, a highly conserved region of the viral replicase gene was selected as silencing target for the development of transgenic rhizomania resistance. Three RNA1 segments differing in size were inserted in an inverted repeat array, an arrangement capable of functioning as a strong silencing inducer (Johansen and Carrington 2001), into the binary vector pK7WIWG2 (II) (Karimi et al. 2002) using the Gateway technology. The resulting binary plant expression vectors GW-IR1, GW-IR2 and GW-IR3 were used for the generation of sugar beet seedlings with transformed hairy roots and non-transformed shoots and leaves.

Transformation was performed by inoculating $A$. rhizogenes strain R1000 at the hypocotyl of aseptically grown seedlings, resulting in the formation of adventitious kanamycin resistant roots approximately 8-10 days post transformation (Fig. 1b). A limited number of adventitious lateral roots appearing on the radicle section were occasionally observed in several seedlings, as a response to the removal of the root apical meristem (Fig. 1c). The emergence of such roots however, was recorded approximately 3-4 days following sectioning and was independent of $A$. rhizogenes transformation, since they were not produced from cells subjected to proper antibiotic pressure.

Hairy roots differed from wild type roots with respect to growth rate, structure and branching. Transgenic roots were profoundly abundant, accompanied by a large number of root extensions, a rapid growth rate and in some cases a plagiotropic development. Untransformed seedlings grown under no selection, developed roots of wild type phenotype approximately 15 days after removal of the existing root system. In contrast, those grown under antibiotic selection did not produce new roots and eventually showed necrosis at the wounded site of the hypocotyls (Fig. 1d). The frequency of cut hypocotyls producing kanamycin resistant hairy roots was $96 \%$ with an average number of 6.5 (range: 5-8) transformed roots per inoculated seedling.

To confirm the presence of the full-length transgene, kanamycin resistant roots were analyzed by a multiplex PCR targeting the BNYVV-derived transgene, the nptII gene and virCD of A. rhizogenes. Amplicons of the expected size were obtained for the BNYVV transgenes of 459,589 or $824 \mathrm{bp}$, and $n p t \mathrm{II}$ of $385 \mathrm{bp}$ in all of the 60 roots examined (Fig. 2). The virCD fragment of $1,074 \mathrm{bp}$ could not be amplified from roots, thus excluding the presence of A. rhizogenes and verifying the transgenic nature of hairy roots grown under kanamycin selection. 


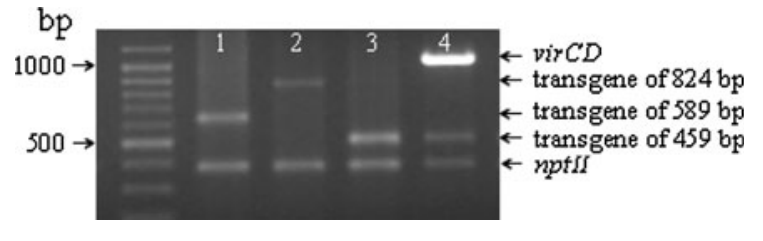

Fig. 2 Amplification products obtained by multiplex PCR for the evaluation of transgenic roots. Lanes 1, 2, 3: A. rhizogenestransformed roots, carrying a BNYVV transgene (589, 824 and $459 \mathrm{bp}$, respectively) and the nptII gene (385 bp). Lane 4: A. rhizogenes cells transformed with GW-IR3, carrying the BNYVV-derived transgene of $459 \mathrm{bp}$. The amplicon of 1,074 bp corresponding to virCD of $A$. rhizogenes could only be amplified using bacterial cells as a template, thus verifying its absence in transgenic roots grown under kanamycin pressure. Ladder used: Gene Ruler Ladder mix (Fermentas)

Furthermore, BNYVV transgene expression was verified by means of a RT-PCR assay, in more than $90 \%$ of the 60 root samples examined (data not shown). These findings, combined with the observed inability of the untransformed seedlings to form roots under antibiotic pressure clearly indicated that selection of transformants was readily achieved on the basis of kanamycin resistance.

\section{BNYVV replicase-derived dsRNA results}

in resistant hairy roots

Challenge-inoculation experiments were performed as a means to assess the ability of intron-hairpin constructs in inducing RNA silencing-based rhizomania resistance to $\mathrm{Ri}$ T-DNA-transformed sugar beet roots. Resistance was assessed by visual symptom observation as well as by measurement of virus titers through ELISA at 14 and 21 dpi. All together, 120 transformed seedlings for every intron-hairpin construct were included in three challenge-inoculation experiments. In untransformed control seedlings, stunting, leaf curling and sporadic chlorosis appeared at $16-20$ dpi and approximately $95 \%$ of these plants exhibited systemic virus disease symptoms at 23-26 dpi (Fig. 3). The same symptom development was observed in challenge-inoculated seedlings transformed with the empty vector only, employed as a means to assess the performance of hairy roots expressing dsRNA originating from an unrelated source.

ELISA readings $\left(\mathrm{OD}_{405}\right)$ were in good agreement with these visual assessments: control plants

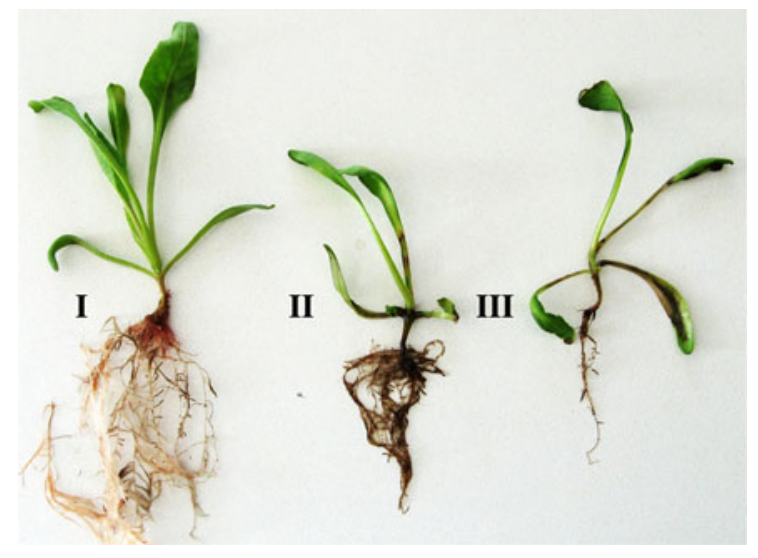

Fig. 3 Symptoms of Beet necrotic yellow vein virus in sugar beet seedlings at 21 days post mechanical root inoculation. I Seedling with a GW-IR3 transgenic root system. II Seedling with vector-transformed root system. III Untransformed seedling with a wild type root system. Transgenic roots carrying a BNYVV replicase-derived hairpin molecule are symptomless, whereas vector-transformed and non-transformed seedlings, exhibit symptoms of root deterioration as well as leaf chlorosis and necrosis

(untransformed and vector-transformed presented together) were found positive at $14 \mathrm{dpi}$ and 115 out of 120 seedlings were fully infected at $21 \mathrm{dpi}$. As expected for BNYVV, the root system of each control seedling scored higher than its leaves. The reading values for roots at $14 \mathrm{dpi}$ ranged from 0.437 to 0.607 whereas values for leaves ranged from 0.281 to 0.343 with the negative controls presenting values from 0.098 to 0.101 for both roots and leaves. The respective figures at $21 \mathrm{dpi}$ were $0.80-1.15$ for roots and $0.60-0.80$ for leaves. Taken all together, the mean content of virus titer in the roots was significantly higher than that of the leaves in both test dates (Table 2).

The majority (>90\%) of A. rhizogenes-transformed seedlings manifested a delay in symptom development of at least 7-10 days compared to control plants (Fig. 3). More than $90 \%$ of the 360 seedlings tested at $14 \mathrm{dpi}$, proved negative for BNYVV infection in both roots and leaves. The virus could be detected only in the leaves of a few seedlings $(<10 \%)$ at a very low, marginally considered as positive $\left(\mathrm{OD}_{405}=0.28-0.35\right)$ level, accompanied by the absence of visual symptoms. At $21 \mathrm{dpi}$, all seedlings had lower values in the roots than it the leaves. At this time, transformed hairy roots from more than $80 \%$ of the plants analyzed were found 
Table 2 Mean of BNYVV ELISA values of three challenge-inoculation experiments

\begin{tabular}{|c|c|c|c|c|c|}
\hline \multirow[t]{3}{*}{ Constructs } & \multicolumn{5}{|l|}{ ELISA readings $\left(\mathrm{OD}_{405}\right)$} \\
\hline & \multirow[t]{2}{*}{ Number of seedlings tested } & \multicolumn{2}{|l|}{14 dpi } & \multicolumn{2}{|l|}{$21 \mathrm{dpi}$} \\
\hline & & Roots & Leaves & Roots & Leaves \\
\hline GW-IR1 & 120 & $0.127(-)^{*}$ & $0.244(-)$ & $0.162(-)$ & $0.607 \mathrm{~B} * *$ \\
\hline GW-IR2 & 120 & $0.118(-)$ & $0.262(-)$ & $0.219(-)$ & $0.720 \mathrm{~A}$ \\
\hline GW-IR3 & 120 & $0.111(-)$ & $0.201(-)$ & $0.116(-)$ & $0.483 \mathrm{C}$ \\
\hline Control*** & 120 & $0.522 \mathrm{a}$ & $0.312 \mathrm{~b}$ & $0.998 \mathrm{a}$ & $0.709 \mathrm{~b} \mathrm{~A}$ \\
\hline
\end{tabular}

Data represent the average $\mathrm{OD}_{405}$ readings of each seedling at 14 and 21 days post inoculation (dpi)

* (-) Value indicative of virus absence (reading for negative control: 0.098-0.102)

** Different letters denote statistically significant differences at $P=0.05$. Small letters refer to horizontal comparisons between roots and leaves (paired $t$-test). Capital letters refer to comparisons among the four categories of means (three constructs and control) ( $F$-test)

*** Average of untransformed and vector-transformed readings

completely virus-free while the rest presented marginally positive values $\left(\mathrm{OD}_{405}=0.26-0.33\right)$. At the same time the aerial, non-transformed parts of the same seedlings were found infected $\left(\mathrm{OD}_{405}=0.32-\right.$ $0.85)$. In addition, given that statistical analysis was meaningful in this case, significant differences among seedlings expressing the different transgenes were found, with those carrying the transgene of $459 \mathrm{bp}$ presenting a better performance than the other two.

Collectively, these results indicate that a good, operational level of BNYVV-resistance was obtained in the transformed roots and further substantiate the conclusion that such resistance can be readily screened in genetically engineered hairy roots. The fact that hairy roots expressing the transgene of $459 \mathrm{bp}$ performed better, as evidenced by the leaf values at $21 \mathrm{dpi}$, may relate to transgene stability; previous studies have also reported on the effect of the size of hairpin constructs in silencing induction capacity and further demonstrated that small hairpins are stronger silencing inducers than larger molecules (Heilersig et al. 2006).

As opposed to previously employed genes encoding for the coat protein or triple gene block proteins (Bleykasten-Grosshans et al. 1997; Andika et al. 2005), the conserved nature of the gene encoding the BNYVV replicase protein renders it a more suitable target for the purposes of achieving durable resistance against rhizomania disease of sugar beets. This kind of resistance, if expressed upon stable transformation and regeneration at the whole plant level, is expected to decrease virus spread in a transgenic crop under field conditions.

Acknowledgments The first author would like to acknowledge the Greek State Scholarships Foundation for funding her studies, in the framework of which this research project was partly conducted.

Open Access This article is distributed under the terms of the Creative Commons Attribution Noncommercial License which permits any noncommercial use, distribution, and reproduction in any medium, provided the original author(s) and source are credited.

\section{References}

Andika IB, Kondo H, Tamada T (2005) Evidence that RNA silencing-mediated resistance to beet necrotic yellow vein virus is less effective in roots than in leaves. Mol Plant Microbe Interact 18(3):194-204

Baulcombe D (1999) Viruses and gene silencing in plants. Arch Virol Suppl 15:189-201

Bernstein E, Caudy AA, Hammond SM, Hannon GJ (2001) Role for a bidentate ribonuclease in the initiation step of RNA interference. Nature 409:363-366

Bleykasten-Grosshans C, Guilley H, Bouzoubaa S, Richards KE, Jonard G (1997) Independent expression of the first two triple gene block proteins of beet necrotic yellow vein virus complements virus defective in the corresponding gene but expression of the third protein inhibits viral cellto-cell movement. Mol Plant Microbe Interact 10:240-246

Brodersen P, Voinnet O (2006) The diversity of RNA silencing pathways in plants. Trends Genet 22(5):268-280

Chuang C-F, Meyerowitz EM (2000) Specific and heritable genetic interference by double-stranded RNA in Arabidopsis thaliana. Proc Natl Acad Sci 97:4985-4990 
D' Halluin K, Bossut M, Bonne E, Mazur B, Leemans J, Botterman J (1992) Transformations of sugar beet (Beta vulgaris L.) and evaluation of herbicide resistance in transgenic plants. Bio/Technol 10:309-314

De Biaggi (2005) Objectives of sugar beet breeding, Rhizomania. In: Biancardi E, Campbell LG, Skaracis GN, de Biaggi M (eds) Genetics and breeding of sugar beet. Science Publishers Inc, Enfield, pp 80-85

Ding S, Voinnet O (2007) Antiviral immunity directed by small RNAs. Cell 130(3):413-426

Fire A, Xu S, Montgomery MK, Kostas SA, Driver SE, Mello CC (1998) Potent and specific genetic interference by double-stranded RNA in Caenorhabditis elegans. Nature 391:806-811

Goldbach R, Bucher E, Prins M (2003) Resistance mechanisms to plant viruses: an overview. Virus Res 92:207-212

Hamilton AJ, Baulcombe DC (1999) A species of small antisense RNA in posttranscriptional gene silencing in plants. Science 286:950-952

Hamilton AJ, Brown S, Yuanhai H, Ishizuka M, Lowe A, Solis AGA, Grierson D (1998) A transgene with repeat DNA causes high frequency, post-transcriptional suppression of ACC-oxidase gene expression in tomato. Plant J 15:737-746

Hamilton A, Voinnet O, Chappell L, Baulcombe D (2002) Two classes of short interfering RNA in RNA silencing. EMBO J 21:4671-4679

Hammond SM (2005) Dicing and slicing: the core machinery of the RNA interference pathway. FEBS Lett 579:58225829

Hammond SM, Bernstein E, Beach D, Hannon GJ (2000) An RNA-directed nuclease mediates post-transcriptional gene silencing in Drosophila cells. Nature 404:293-296

Hammond SM, Caudy AA, Hannon GJ (2001) Post-transcriptional gene silencing by double-stranded RNA. Nat Rev Genet 2(2):110-119

Heilersig HJ, Loonen A, Bergervoet M, Wolters AM, Visser RG (2006) Post-transcriptional gene silencing of GBSSI in potato: effects of size and sequence of the inverted repeats. Plant Mol Biol 60(5):647-662

Johansen LK, Carrington JC (2001) Silencing on the spot. Induction and suppression of RNA silencing in the Agrobacterium-mediated transient expression system. Plant Physiol 126:930-938

Johansson E (1985) Rhizomania in sugar beet-a threat to beet growing that can be overcome by plant breeding. Sveriges Utsädesförenings Tidskrift 95:115-121

Kalmykova AI, Klenov MS, Gvozdev VA (2005) Argonaute protein PIWI controls mobilization of retrotransposons in the Drosophila male germline. Nucl Acid Res 33(6): 2052-2059

Karimi M, Inzé D, Depicker A (2002) GATEWAY ${ }^{\mathrm{TM}}$ vectors for Agrobacterium-mediated plant transformation. Trends Plant Sci 7:193-195

Koenig R, Stein B (1990) Distribution of beet necrotic yellow vein virus in mechanically inoculated sugar beet plantlets of cultivars with different degrees of Rhizomania resistance. Schriften Deutsch Phytomed Gesel 1:87-89

Krens FA, Trifonova A, Keizer PLC, Hall RD (1996) The effect of exogenously-applied phytohormones on gene transfer efficiency in sugarbeet (Beta vulgaris L.). Plant Sci 116:97-106
Lennefors B-L, Savenkov EI, Bensefelt J, Wremerth-Weich E, van Roggen P, Tuvesson S, Valkonen JPT, Gielen J (2006) dsRNA-mediated resistance to Beet Necrotic Yellow Vein Virus infections in sugar beet (Beta vulgaris L. ssp. vulgaris). Mol Breed 18:313-325

Lohmann JU, Endl I, Bosch TCG (1999) Silencing of developmental genes in Hydra. Dev Biol 214:211-214

Napoli C, Lemieux C, Jorgensen R (1990) Introduction of a chimeric chalcone synthase gene into Petunia results in reversible co-suppression of homologous genes in trans. Plant Cell 2:279-289

Ngo H, Tschudi C, Gull K, Ullu E (1998) Double-stranded RNA induces mRNA degradation in Trypanosoma brucei. Proc Natl Acad Sci 95:14687-14692

Skaracis GN (2005) Molecular biology and biotechnology, genetic engineering. In: Biancardi E, Campbell LG, Skaracis GN, de Biaggi M (eds) Genetics and breeding of sugar beet. Science Publishers Inc, Enfield, pp 255-268

Smith NA, Singh SP, Wang MB, Stoutjesdijk PA, Green AG, Waterhouse PM (2000) Total silencing by intron-spliced hairpin RNAs. Nature 407:319-320

Song Ji-J, Smith SK, Hannon GJ, Joshua-Tor L (2004) Crystal structure of Argonaute and its implications for RISC slicer activity. Science 305(5689):1434-1437

Stam M, Mol JNM, Kooter JM (1997) The silence of genes in transgenic plants. Ann Bot 79:3-12

Tabara H, Sarkissian M, Kelly WG, Fleenor J, Grishok A, Timmons L, Fire A, Mello CC (1999) The rde-1 gene, RNA interference and transposon silencing in C. elegans. Cell 99:123-132

Tamada T, Baba T (1973) Beet necrotic yellow vein virus from rhizomania-affected sugar beet in Japan. Ann Phytopathol Soc Jpn 39:325-332

Tenllado F, Llave C, Diaz-Ruiz JR (2004) RNA interference as a new biotechnological tool for the control of virus diseases in plants. Virus Res 102:85-96

Tijsterman M, Ketting RF, Plasterk RHA (2002) The genetics of RNA silencing. Ann Rev Genet 36:489-519

Vagin VV, Sigova A, Li C, Seitz H, Gvozdev V, Zamore PD (2006) A distinct small RNA pathway silences selfish genetic elements in the germline. Science 313(5785):320324

van der Krol AR, Mur LA, Beld M, Mol JN, Stuitje AR (1990) Flavonoid genes in petunia: addition of a limited number of gene copies may lead to a suppression of gene expression. Plant Cell 2(4):291-299

Vazquez RC, del Vas M, Hopp HE (2002) RNA-mediated virus resistance. Curr Opin Biotechnol 13:167-172

Voinnet O (2001) RNA silencing as plant immune system against viruses. Trends Genetic 17(8):449-459

Voinnet O (2008) Post-transcriptional RNA silencing in plantmicrobe interactions: a touch of robustness and versatility. Curr Opin Plant Biol 11(4):464-470

Waterhouse PM, Gramham M, Wang MB (1998) Virus resistance and gene silencing in plants can be induced by simultaneous expression of sense and antisense RNA. Proc Natl Acad Sci USA 95:13959-13964

Waterhouse PM, Wang MB, Lough T (2001) Gene silencing as an adaptive defence against viruses. Nature 411:834-842

Wozniak CA (1999) Transgenic sugar beet: progress and development. Appl Plant Biotech 10:301-324 